\title{
Chemical Treatment of Black Tiger nut Tubers (Cyperus escu- lentus) Variety to Obtain a Bio-based Product
}

\author{
Djomdi $^{12^{*}}$, Richard Ejoh ${ }^{1}$, Guillaume Pierre ${ }^{3}$, Cedric Delattre ${ }^{3,4}$, Philippe Michaud ${ }^{3}$ And Robert Ndjouenkeu ${ }^{1}$
}

\author{
1Dept of Food Science and Nutrition, University of Ngaoundéré, P.O.Box 455 Ngaoundéré, Cameroon \\ ${ }^{2}$ National Advanced School of Engineering, University of Maroua P.O. Box 46 Maroua, Cameroon \\ ${ }^{3}$ Université Clermont Auvergne, CNRS, SIGMA Clermont, Institut Pascal, F-63000 Clermont-Ferrand, France, \\ France; \\ ${ }^{4}$ Institut Universitaire de France (IUF), 1 Rue Descartes, 75005 Paris, France. \\ ** To whom all correspondences should be addressed Phone: +237 699626764 E-mail: ngdjomdi@yahoo.fr
}

\begin{abstract}
Black variety of tiger nut tubers (Cyperus esculentus) were differently processed in ascorbic acid and alkaline $\left(\mathrm{Ca}(\mathrm{OH})_{2}\right.$ and Kanwa) solutions at different concentrations and temperatures. The effect of these treatments on the water content (swelling), soluble loss, dehulling efficiency and microbial load was investigated. Water content or swelling of the tiger nut soaked in acid and alkaline solutions can be predicted by Peleg model like with brown variety. This swelling lead to enhance dehulling efficiency of tuber but caused soluble solute loss overall at the highest temperature of soaking in vitamin C solution. Like soaking in water, the constant of Peleg $\left(k_{1}\right)$ decrease with the increase of the temperature of soaking, whereas the constant of capacity of Peleg $\left(k_{2}\right)$ is approximately $0.018 \%$ for all the conditions. Dehulling efficiency also increased with increasing temperatures $\left(65 \%\right.$ at $20^{\circ} \mathrm{C}$ to $70 \%$ at $\left.60^{\circ} \mathrm{C}\right)$ for tiger nut tubers soaked in water $(0 \mathrm{~g} / \mathrm{L})$, dehulling efficiency appeared most strongly affected by concentrations and temperatures of soaking solutions. Like dehulling efficiency, ascorbic solutions has given the best results in term of reduction of microbial load compared to the other soaking solutions. This reduction is considerable at the higher temperatures, reaching a maximum of $4.8 \mathrm{log}$ reduction. Soaking and dehulling treatments gave to tiger nut tuber effective decontamination in term of microbial load and obtained good microbiological quality for final process.
\end{abstract}

Keywords: Cyperus esculentus, soaking, husking, microorganism, tiger nuts, black tubers

\section{Introduction}

Black variety of tigernut tubers (Cyperus esculentus) are used for production of vegetable milk or few data are available in literature concerning pretreatment of tubers, extraction and biochemical composition of milk [1a-4]. In Spain, brown variety is used in the production of a milky drink called "horchata de chufa". High level of microorganisms such as bacteria and moulds (more than $10^{\circ} \mathrm{cfu} / \mathrm{ml}$ ) have been detected in it; limiting its shelf life (less than 24 hours) [5-7]. These micro-organisms originate from the rugous surface of the tuber where they are encrusted in the anfractuosities of the collenchyma sleeve [6-8]. The rough structure of the tuber surface does not allow the easy elimination of micro-organisms, even when using sodium hypochlorite [7].

Tubers soaked in water during several hours undergo a turgescence which results in an easy elimination of the tuber external skin $[9,10]$. This turgescence is not observed with hypochlorite solution after 48 hours, suggesting the processing time is not sufficient. So, the research of a cleansing process of tiger nut tubers remains a major concern for a better use of them in the production of vegetable milk. It proves to be important to test treatments having given convincing results with other raw materials requiring a dehulling process [10].

The swelling of tiger nut tuber consecutive to soaking in acid or alkaline solutions is likely to facilitate its dehulling. These treatment are consequently better elimination of its initial microbial load according to previous studies focusing on the dehulling of black 
bean and maize grains by treatment with alkaline solutions [11, 12] and Solutions of calcium hydroxide, Kanwa (alkaline calcium carbonate locally used to soften vegetables and ascorbic were used for this purpose like describe by Djomdi et al. [1a].

\section{Materials and Methods}

Preparation of samples

Black variety of tiger nut tubers were bought on the market of Guily in the Far-north Region of Cameroon, which is the most producing zone of these foodstuffs (Figure 1). Tubers were sorted by screening on metallic sieve in order to retain tubers with diameter $\geq 1 \mathrm{~cm}$. The tubers were then washed with tap water to remove sands and other undesirable materials (stones, pebbles, dirt materials, rotten stems and broken tubers), then sun dried [10].
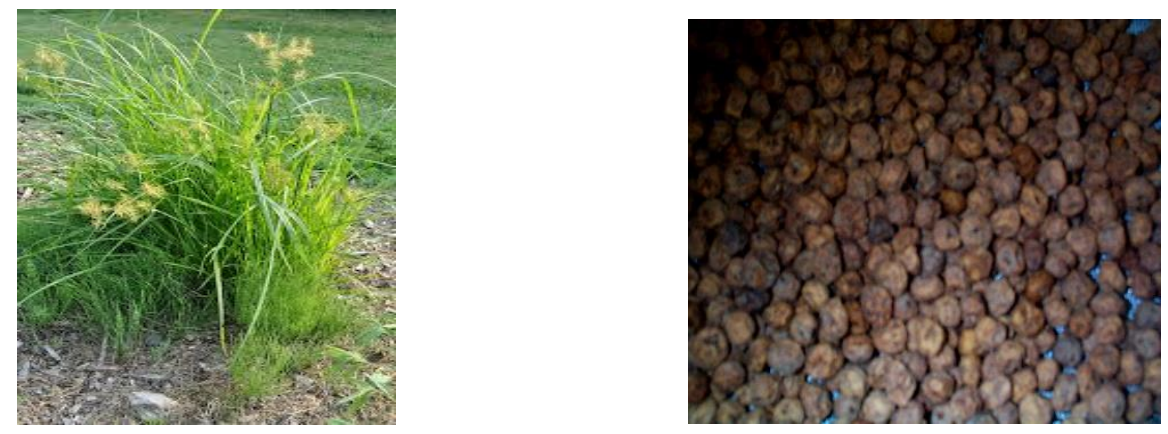

Figure 1: Tigernut plant and black variety tubers

\section{Soaking experiments}

Soaking was undergone according to the methods of Turhan et al. [13], Sayar \& Gunasekaran [14] and Djomdi et al. [10] and Djomdi et al. [15b]. The process consists in soaking the tubers in beakers of $250 \mathrm{~mL}$ containing $100 \mathrm{~mL}$ solution of $\mathrm{Ca}(\mathrm{OH}) 2$, kanwa or ascorbic acid at 20,40 and $60^{\circ} \mathrm{C}$. The beakers were placed in a constant temperature water bath for temperature uniformity during tests. For each experiment, $20 \mathrm{~g}$ of tubers, were immersed in the beaker. During soaking, tubers were periodically removed, superficially dried with a tissue paper and weighed for water retention capacity up to attain an equilibrium value; i.e. when the increment change in sample weight was less than $0.01 \mathrm{~g}$. At least three experiments were conducted for every solution concentration and soaking temperature.

The factors of variation of the treatments were:

-Nature of the solutions: calcium hydroxide, Kanwa and ascorbic acid.

-Concentrations of the solutions: $0 ; 0.1 ; 0.5 ; 1$ and $1.5 \%(w / v)[11,12,15 b]$.

-Temperatures of treatment: 20,40 and $60^{\circ} \mathrm{C}[10,15 \mathrm{~b}]$.

The Water absorption capacity of the samples at each time $\left(\mathrm{H}_{\mathrm{t}}\right)$ was calculated based on the increase in weight of the samples using Peleg model (Eq. 1) [16, 17]:

$$
\mathrm{H}_{\mathrm{t}}=\mathrm{H}_{0}+\frac{\mathrm{t}}{\mathrm{k}_{1}+\mathrm{k}_{2} \mathrm{t}}
$$

Where: $\mathrm{H}_{\mathrm{t}}(\% \mathrm{DW})$ is the moisture content at time $\mathrm{t}$

$\mathrm{H}_{0}(\% \mathrm{DW})$ is the initial moisture content

$\mathrm{k}_{1}(\mathrm{~h} . \%-1)$ is the Peleg rate constant which is related to absorption rate at the beginning of the process $(\mathrm{t}=\mathrm{t} 0)$ content (tø®)

$\mathrm{k}_{2}(\%-1)$ is the Peleg capacity constant related to maximum attainable moisture 
The model is linearized into the form:

$$
\frac{\mathrm{t}}{\mathrm{H}_{\mathrm{t}}-\mathrm{H}_{\mathrm{O}}}=\mathrm{k}_{1}+\mathrm{k}_{2} \mathrm{t}
$$

$\mathrm{k}_{1}$ and $\mathrm{k}_{2}$ constants are determined from the regression of $\mathrm{t} /\left(\mathrm{H}_{\mathrm{t}}-\mathrm{H}_{0}\right) \mathrm{vs}$. time.

Peleg constants ( $\mathrm{k}_{1}$ and $\mathrm{k}_{2}$ ) values obtained were used in Equation 2 [1, 15b] to calculate predicted values of moisture content $(\mathrm{Hp})$ which were then compared to the corresponding experimental values in order to appreciate the goodness of fit of the Peleg model. The criterion used to evaluate the goodness of fit was the mean relative percentage deviation $(p)$ between experimental data and theoretical values $(18,15 b)$ calculated as:

$$
\mathrm{p}(\%)=\frac{100}{\mathrm{~N}} \sum_{\mathrm{i}=1}^{\mathrm{N}} \frac{\left|\mathrm{H}_{\mathrm{ei}}-\mathrm{H}_{\mathrm{pi}}\right|}{\mathrm{H}_{\mathrm{ei}}}
$$

Where: $\quad \mathrm{H}_{\mathrm{ei}}$ and $\mathrm{H}_{\mathrm{pi}}$ are respectively experimental and predicted moisture content values. $\mathrm{N}$ is the number of experimental data.

The model is considered acceptable if $\mathrm{p}$ values are below $10 \%[19,20]$.

\section{Dehulling of tubers}

At the end of soaking and swelling process, the dehulling consisted in removing the outer protective casing of the tuber by abrasion through scrubbing of the tubers between the hands. Dehulling efficiency was calculated using the formula suggested by Doehlert and Wiessenborn [21] in which the mass percentage of dehulled tubers is compared to that of the whole tubers on dry matter basis.

To account for moisture change during soaking, the mass of tuber samples was measured before and after soaking and dehulling. Moisture correction factor (MFC) was calculated using Eq. 4.

$$
\mathrm{MFC}=\frac{\mathrm{W}_{\mathrm{t}}}{100-\mathrm{H}}
$$

With: $\quad W_{t}(\mathrm{~g})$ : whole tuber mass with hulls

$\mathrm{H}(\%)$ : water content of the tubers

In addition, at the end of swelling and after dehulling, the hulls were weighed, dried at $105^{\circ} \mathrm{C}$ for 24 hours and reweighed to obtain a dry mass $(\mathrm{Mh})$.

The dehulling efficiency is then given by the Eq. 5:

$$
\operatorname{DHE}(\%)=\frac{\mathrm{W}_{\mathrm{t}}-\left(\mathrm{M}_{\mathrm{h}} * \mathrm{MCF}\right)}{\mathrm{W}_{\mathrm{t}}} * 100
$$

Moreover, the solute losses during soaking at different temperatures were calculated according to Evranuz and Gürtas [22]. A known quantity of soaking solution (v) was taken at the end of process, filtered using filter paper Whatman $n^{\circ} 3$, dried in oven at $105^{\circ} \mathrm{C}$ for 24 hours and weighed $(\mathrm{m})$.The solute losses were expressed in $\mathrm{g} / 100 \mathrm{~g}$ dry weight basis (Eq. 6).

$$
\mathrm{SL}=\frac{\mathrm{m} * \mathrm{~V} * 100 * 100}{(100-\mathrm{H}) * \mathrm{~V} * \mathrm{M}}
$$

With:

SL (g/100 g DW): Solute loss

$\mathrm{m}(\mathrm{g})$ : mass of soluble obtained after drying of $\mathrm{v}$ aliquot

$\mathrm{V}(\mathrm{ml})$ : total volume of soaking solution

$\mathrm{v}(\mathrm{ml})$ : aliquot volume of the soaking solution

$\mathrm{H}(\%)$ : water content of the tubers 


\section{$M(g)$ : mass of tubers before soaking}

\section{Microbiological analyzes}

The microbiological analyzes were performed according to standards methods [23]. The research of the total microbial count was carried out by macerating tiger nut tubers in a sterile food processor. Ten g of each sample of tiger nut tubers (raw, soaked and dehulled) were crushed in a mortar in asepsis conditions. One g of the crushed sample was mixed with $9 \mathrm{~mL}$ of sterile physiological water solution $(9 \mathrm{~g}$ of $\mathrm{NaCl}$ in $1 \mathrm{~L}$ of distilled water) and the mixture used for the preparation of decimal dilutions of 10-2 to 10-9 and the highest three dilutions were taken for analysis.

Enumeration was carried out by counting of the colonies (CFU). The count was carried out in triplicates.

All results are expressed as mean values of three separate determinations.

\section{Results and discussion}

\subsection{Water absorption of black variety of tiger nut tuber in ascorbic acid, Kanwa and calcium hy- droxide solutions}

Soaking is a long stage process in which the goal is the swelling of tiger nut tubers. During immersion, there is material transfer made both of soluble between tubers and the solution. For all the soaking solutions, tiger nut tubers showed typical sorption behavior with exponentially water content versus soaking time at all the temperatures (Fig. 2). As the process continued, water absorption rate steadily decreased due to filling of water into free capillary and intermicellar increasing extraction rates of soluble solids from tubers. The absorption ceased when the tubers attained the equilibrium water content [15b].

The kinetics absorption of solution by black tiger nut tubers at various temperatures and concentrations of ascorbic acid, Kanwa and $\mathrm{Ca}(\mathrm{OH})_{2}$ showed that the rate of absorption of water increased with the temperature of soaking like described by Djomdi et al. [15b]. Tables 1 and 2 show that no significant difference $(p<0.05)$ was observed between the constants $\mathrm{k}_{1}$ and the increase of the concentration whatever the treatment applied, as previously reported for tubers from brown variety $(10,15 b)$. However, a significant difference $(p<0.05)$ between constancies $k_{1}$ and the increase of the temperature, whatever the treatment applied, was logically detected as an increasing temperature was correlated with a faster absorption of water reducing time of soaking (Fig. 2). The constant of Peleg $\left(\mathrm{k}_{1}\right)$ decreased with the increase of soaking temperature, whereas the constant of capacity of Peleg $\left(\mathrm{k}_{2}\right)$ was approximately $0.02 \%$ for all the conditions of soaking. There is a relative stability of the values of $\mathrm{k}_{2}$ for all the temperatures and concentration of soaking. Djomdi et al. $[10,15 \mathrm{~b}]$ reported that chemical modification of the tubers under the effect of the temperature (gelatinization) did not affect their capacity of water absorption. $\mathrm{k}_{1}$ is a constant connected at the rate of transfer of the matter. The weakness of the cellular membrane due to heating, increased the cellular permeability, involving for higher absorption solution by the tubers. This absorption was not constrained by the various treatments applied to the tubers during soaking. This phenomenon was observed by other authors and it was attributed to plasticizing effect of water at the temperature of starch gelatinization $[10,13-15,24]$.

The fit of Equation (2) to absorption data showed that, at all soaking conditions, the degree of fit, judged by regression coefficient $\left(\mathrm{r}^{2}\right)$, was about the same. Tables 1 and 2 provide the resulting Peleg constants $\left(\mathrm{k}_{1}\right.$ and $\left.\mathrm{k}_{2}\right), \mathrm{r}^{2}$ and $\mathrm{p}$ values. The use of kinetic data to determine the goodness of fit of the Peleg model resulted in a fit with $r^{2} \geq 0.90$ at almost all soaking conditions (solutions concentrations, temperature and time). The relative deviation between experimental and predicted data is around 2.798-6.167 indicating that water absorption of tiger nut tubers during soaking in acid and alkali solution is well described by the Peleg model [25]. 
It should be noted that the diffusion was not done in one way as the tubers also lost solutes in the soaking solutions (fig. 3) meaning that soaking solutions were not sufficiently concentrated to prevent the opposite transfer of matter.

The losses of soluble solids from tubers at 20 and $40^{\circ} \mathrm{C}$ were less than 0.5 and $2 \%$ $(\mathrm{w} / \mathrm{w})$ respectively. Sayar et al. [14] stipulated that these values can be negligible compared to water gain. However at $60{ }^{\circ} \mathrm{C} 8.7 \%(\mathrm{w} / \mathrm{w})$ of tuber solutes were recovered in soaking solutions. So, even if solutions at temperature of $60{ }^{\circ} \mathrm{C}$ and above accelerate the water absorption, they lead to significant damage in structure and tissue of tiger nut tubers. This phenomenon was not identified for ascorbic acid solutions indicating that higher concentration of osmolytes slowed down soluble solids loss even if higher temperature inactive and decompose ascorbic acid [26].

This part of work established the suitability of the model of Peleg to describe the behavior of the tubers of $C$. esculentus L. at the time of soaking $[10,1 b 5]$. The high temperatures accelerate the phenomenon of absorption of water and loss of soluble solutes [15b]. Although the heating contributes to sterilize the tubers, with regard to the microbial load [27]. So the effects of the temperature and the nature of soaking solutions was investigated on the dehulling of tiger nut tubers. 
Table 1: Water absorption constants and goodness of fit of Peleg model of black variety of tigernut tubers soaked in alkaline solutions $\left(\mathrm{Ca}(\mathrm{OH})_{2}\right.$ and Kanwa) at different temperatures.

\begin{tabular}{|c|c|c|c|c|c|c|c|c|c|}
\hline \multirow[b]{2}{*}{$C(\mathrm{~g} / \mathrm{L})$} & \multirow[b]{2}{*}{$\mathrm{T}\left({ }^{\circ} \mathrm{C}\right)$} & \multicolumn{4}{|l|}{$\mathrm{Ca}(\mathrm{OH})_{2}$} & \multicolumn{4}{|l|}{ Kanwa } \\
\hline & & $\mathbf{k}_{1}$ & $\mathbf{k}_{2}$ & $\mathbf{r}^{2}$ & P (\%) & $\mathbf{k}_{1}$ & $\mathbf{k}_{2}$ & $\mathbf{r}^{2}$ & $P(\%)$ \\
\hline \multirow{3}{*}{0} & 20 & $0.2352^{a}$ & 0.019 & 0.97 & 4.002 & $0.2342^{a}$ & 0.0181 & 0.973 & 4.381 \\
\hline & 40 & $0.1009^{b}$ & 0.0176 & 0.969 & 4.653 & $0.1006^{b}$ & 0.0172 & 0.957 & 4.083 \\
\hline & 60 & $0.0505^{c}$ & 0.0174 & 0.985 & 4.489 & $0.0472^{c}$ & 0.0190 & 0.982 & 4.489 \\
\hline \multirow{3}{*}{0.1} & 20 & $0.2957^{a}$ & 0.0174 & 0.961 & 5.324 & $0.3023^{a}$ & 0.0159 & 0.981 & 5.743 \\
\hline & 40 & $0.0987^{b}$ & 0.0168 & 0.972 & 4.753 & $0.1312^{b}$ & 0.0192 & 0.981 & 4.853 \\
\hline & 60 & $0.0343^{c}$ & 0.0192 & 0.963 & 5.123 & $0.0443^{c}$ & 0.0191 & 0.979 & 4.681 \\
\hline \multirow{3}{*}{0.5} & 20 & $0.3167^{a}$ & 0.0173 & 0.915 & 4.783 & $0.2593^{a}$ & 0.0177 & 0.97 & 4.407 \\
\hline & 40 & $0.1492^{b}$ & 0.0169 & 0.972 & 3.836 & $0.1274^{b}$ & 0.0194 & 0.981 & 4.097 \\
\hline & 60 & $0.0391^{c}$ & 0.0178 & 0.983 & 4.657 & $0.0348^{c}$ & 0.0187 & 0.979 & 4.984 \\
\hline \multirow{3}{*}{1} & 20 & 0.2959a & 0.0183 & 0.971 & 4.534 & $0.2692^{a}$ & 0.0197 & 0.975 & 4.853 \\
\hline & 40 & $0.1554^{b}$ & 0.0181 & 0.975 & 5.534 & $0.1402^{b}$ & 0.0179 & 0.979 & 4.773 \\
\hline & 60 & $0.0438^{c}$ & 0.0186 & 0.991 & 5.634 & $0.0402^{c}$ & 0.0193 & 0.978 & 3.982 \\
\hline \multirow{3}{*}{1.5} & 20 & $0.2931^{\mathrm{a}}$ & 0.0178 & 0.972 & 5.423 & $0.3004^{\mathrm{a}}$ & 0.0176 & 0.974 & 5.298 \\
\hline & 40 & $0.1007 \mathrm{~b}$ & 0.0167 & 0.942 & 3.518 & $0.1802^{b}$ & 0.0183 & 0.973 & 4.269 \\
\hline & 60 & $0.0398^{c}$ & 0.0174 & 0.941 & 5.005 & $0.0334^{c}$ & 0.0193 & 0.983 & 4.582 \\
\hline
\end{tabular}

Means within the same column followed by same letter are not significantly different using one-way ANOVA test $(\mathrm{P}<0.05)$ 
Table 2 : Water absorption constants and goodness of fit of Peleg model of tiger nut tubers soaked in ascorbic acid at different temperatures

\begin{tabular}{|c|c|c|c|c|c|}
\hline$C(g / L)$ & $\mathrm{T}\left({ }^{\circ} \mathrm{C}\right)$ & $\mathbf{k}_{1}$ & $\mathbf{k}_{2}$ & $\mathbf{r}^{2}$ & $\mathbf{P}(\%)$ \\
\hline & 20 & $0.2163^{a}$ & 0.0184 & 0.98 & 4.105 \\
\hline \multirow[t]{3}{*}{0} & 40 & $0.1103^{b}$ & 0.0176 & 0.975 & 4.721 \\
\hline & 60 & $0.0432^{c}$ & 0.0191 & 0.99 & 4.923 \\
\hline & 20 & $0.2252^{\mathrm{a}}$ & 0.0198 & 0.98 & 4.234 \\
\hline \multirow[t]{3}{*}{0.1} & 40 & $0.1025^{b}$ & 0.0179 & 0.971 & 5.035 \\
\hline & 60 & $0.0492^{c}$ & 0.0193 & 0.986 & 4.234 \\
\hline & 20 & $0.2725^{a}$ & 0.0177 & 0.982 & 5.173 \\
\hline \multirow[t]{3}{*}{0.5} & 40 & $0.1192^{\mathrm{b}}$ & 0.0188 & 0.981 & 4.834 \\
\hline & 60 & $0.0472^{c}$ & 0.0187 & 0.983 & 4.934 \\
\hline & 20 & $0.3021^{a}$ & 0.0177 & 0.97 & 5.034 \\
\hline \multirow[t]{3}{*}{1} & 40 & $0.1023^{b}$ & 0.0187 & 0.978 & 4.089 \\
\hline & 60 & $0.0469^{c}$ & 0.0196 & 0.969 & 4.823 \\
\hline & 20 & $0.2243^{a}$ & 0.0187 & 0.982 & 4.506 \\
\hline \multirow[t]{2}{*}{1.5} & 40 & $0.1243^{b}$ & 0.0184 & 0.979 & 5.894 \\
\hline & 60 & $0.0403^{c}$ & 0.0193 & 0.969 & 4.532 \\
\hline
\end{tabular}

Means within the same column followed by same letter are not significantly different using one-way ANOVA test $(P<0.05)$

1.2.1.1. Dehulling efficiency of black tigernut tubers

The tough outer skin of tiger nut tubers consists of thin epidermis wrapped in the tegument [15b]. It is a very thin coat composed mainly of fibers and called fibro-collenchyma sleeve. This coat was removed by alkaline and acid action of soaking solutions [15b].

Fig. 4 shows dehulling efficiency of soaking solutions (acid and alkaline) at different temperatures. This figure shows that dehulling efficiency increased with increasing concentration of soaking solutions for all the three solutions tested. Significant variations in dehulling efficiency of solutions at 20 and $40^{\circ} \mathrm{C}$ was also detected (15b). At these temperatures, ascorbic has the best dehulling efficiency for all the concentrations but at $60^{\circ} \mathrm{C}$ this activity is reduced compare to the two other solutions. This reduction activity can be attributed to temperature effect on ascorbic acid as explained previously by Marta et al. [26] and Djomdi et al. [15b]. Ascorbic acid exhibited the highest dehulling efficiency for all the temperature except at $60^{\circ} \mathrm{C}$.

At the highest concentrations $(1.5 \mathrm{~g} / \mathrm{L})$, most of the solutions had dehulling efficiency higher than $85 \%$. Dehulling efficiency also increased with increasing temperatures $((<65 \%$ at $20^{\circ} \mathrm{C}$ to $>70 \%$ at $\left.60^{\circ} \mathrm{C}\right)$ ) for tiger nut tubers soaked in water. It appeared most strongly affected by concentrations and temperatures of soaking solutions [15b].

\subsection{Microbial load of black tiger nut tubers before and after treatments}

The control sample (raw tubers) had microbial load up to $109 \mathrm{CFU} / \mathrm{g}$, which is very higher compared to microbiological limits standards (106-<107 CFU/g) (28). Soaking at lower temperatures $\left(20\right.$ and $\left.40^{\circ} \mathrm{C}\right)$ and concentrations $(0.1$ and $0.5 \mathrm{~g} / \mathrm{L})$ increased microbial 
load of black tiger nut tubers varieties for the three solutions. Soaking in these conditions stimulated microbial growth by activating microorganisms as described by Shamsudden and Magashi, (29) and Djomdi et al. (15b). On the contrary, high temperature led to a reducing of microbial load, but the greatest reduction was carried out by dehulling process (15b). Figure 5 shows significant effect of dehulling on the microbial load of tiger nut tuber as for all treatments $2.5 \mathrm{log}$ of microbial reduction was meaured. This result is in agreement with the work of Muthomi et al. (30) and Bashir (31) who reported that semiprocessed maize grains had lower microbial load.

Ascorbic acid solutions gave the best results in term of reduction of microbial load compared to the other soaking solutions (32). This reduction is considerable at the higher temperatures, reaching a maximum of $4.8 \log$ reduction $(33,34)$. According to Marta et al. (26), the main product resulting from thermal ascorbic acid decomposition is dehydro- $\mathrm{L}$ ascorbic acid. This compound seem then to have a similar effect as ascorbic acid in term of dehulling efficiency and microbial load reduction $(35,36)$.

Soaking and dehulling treatments led to tiger nut tuber effective decontamination in term of microbial load and good microbiological quality. 
Water absorption at $20^{\circ} \mathrm{C}$
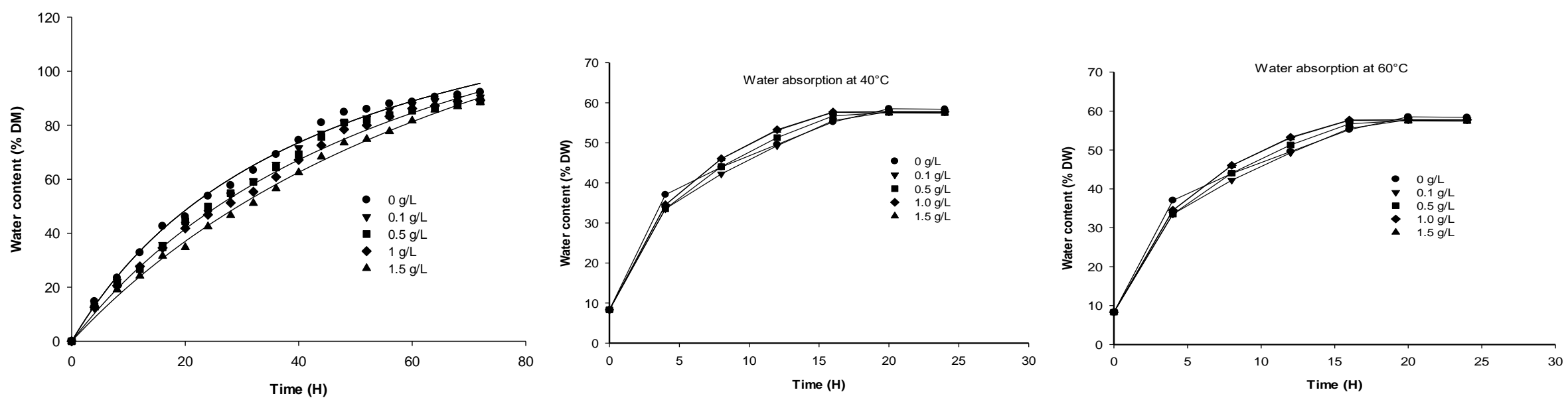

Figure 2: Water absorption of tiger nut tubers soaked in ascorbic acid ( - ) $\mathrm{Ca}(\mathrm{OH})_{2}(---)$ and Kanwa ( ......) solutions at different temperatures.
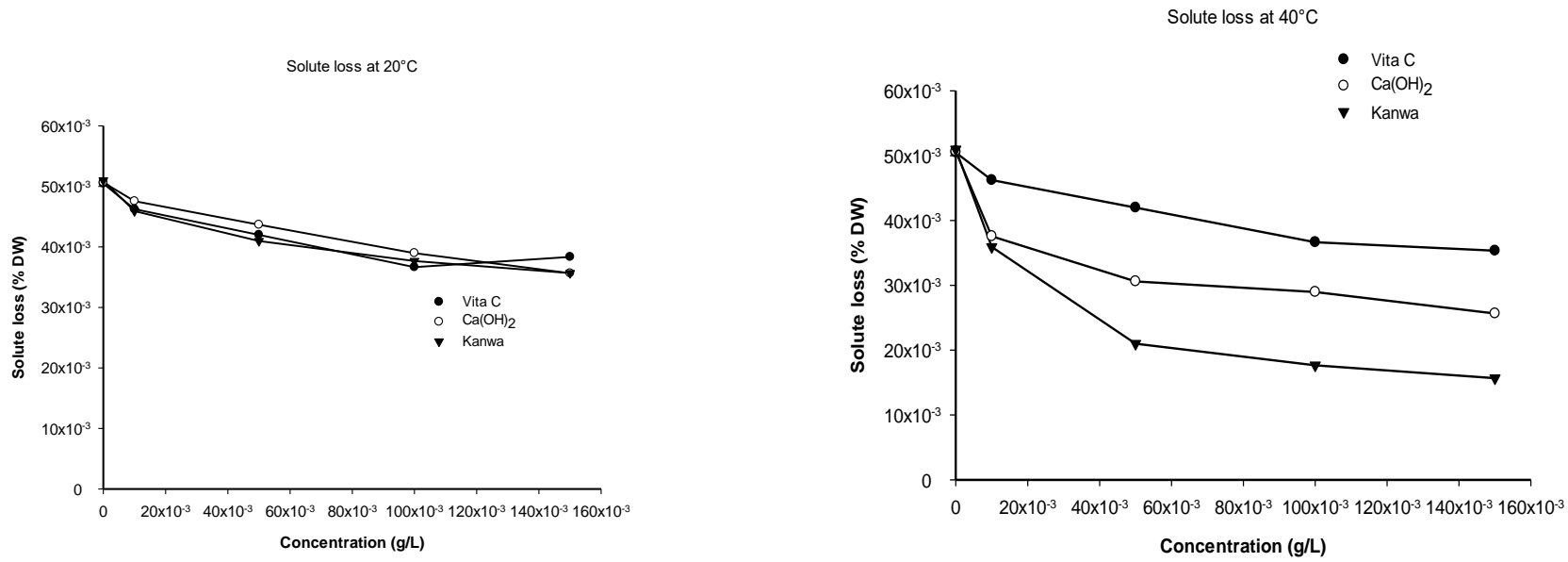

Figure 3: Soluble solids loss of tiger nut tubers soaking at different temperatures

\section{Preprints (umur.prepinis.org) | NOT PEER-REVIEUED । Posted: 16 August 2021}

Solute loss at $40^{\circ} \mathrm{C}$ Concentration $(\mathrm{g} / \mathrm{L})$

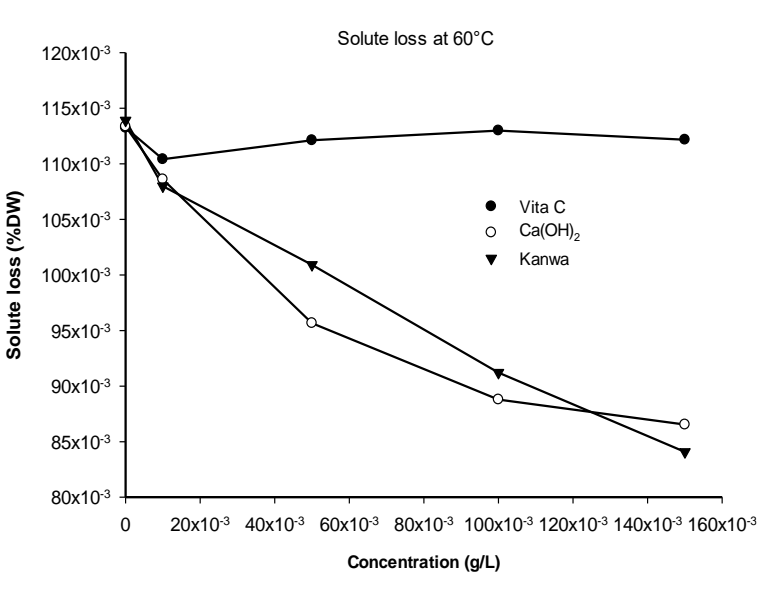

4
5
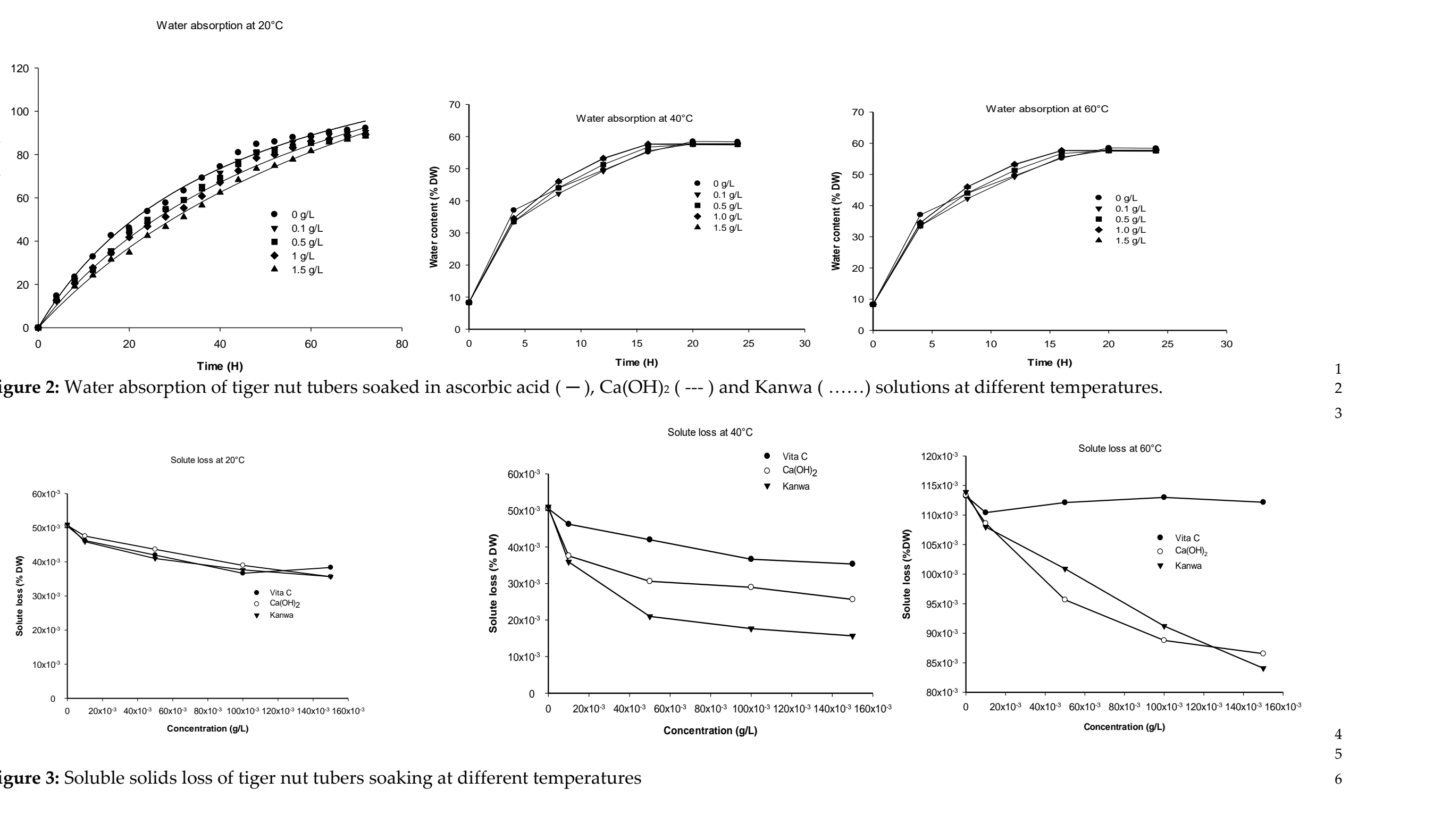

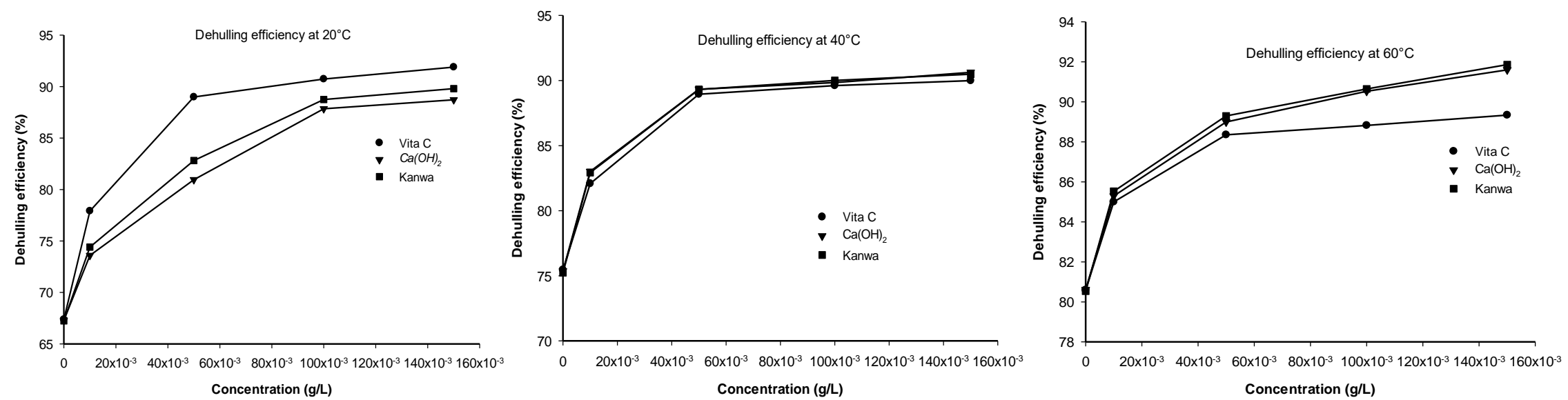

Figure 4: Dehulling efficiency of tiger nut tubers soaked at different temperatures in vitamin $\mathrm{C}, \mathrm{Ca}(\mathrm{OH})_{2}$ and kanwa solutions
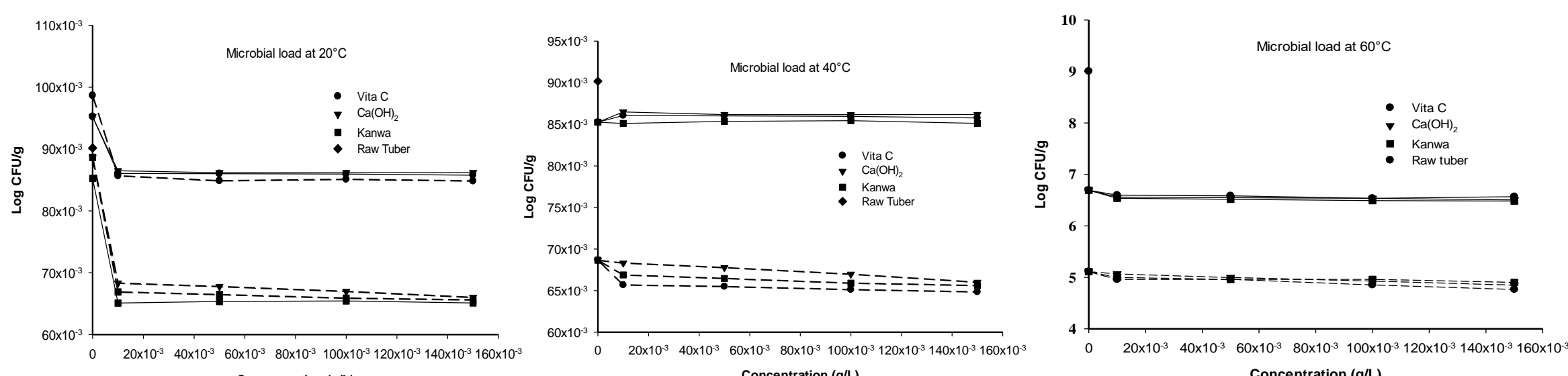

Figure 5: Microbial load of undehulled ( - ) and dehulled ( - - ) tiger nut tubers soaked in vitamin C, $\mathrm{Ca}(\mathrm{OH})_{2}$ and Kanwa solutions 


\section{Conclusions}

The hydrothermal treatment of black tiger nut tubers variety of tiger nut tubers in acid and alkaline solutions contributed to enhance dehulling efficiency and microbial load reduction. Since there was considerable reduction of microbial load at the higher temperature with ascorbic acid based soaking treatments. These treatments led to important soluble solids loss, which compromising nutritional and organoleptic qualities of tiger nut tubers.

The impact of ascorbic acid on dehulling efficiency and microbial load demonstrated that research must be continued with regard for the using of alternative acid solutions like acetic acid, lemon extracts for lowering this processing cost like on brown varieties tubers.

* To whom all correspondences should be addressed Phone: +237 699626764

E-mail: ngdjomdi@yahoo.fr 


\begin{abstract}
Author Contributions: Conceptualization, Djomdi; methodology, Djomdi and Ejoh R.; software, Delattre C.; validation, Djomdi and Michaud P.; formal analysis, Djomdi; Investigation, Djomdi and Pierre G.; resources, Djomdi and Delattre C.; data curation, Ejoh R.; writing-original draft preparation, Djomdi; writing - review and editing, Djomi and Pierre G.; supervision, Michaud P. and Ndjouenkeu R.; project administration, Djomdi and C.D.; funding acquisition, D. All authors have read and agreed to the published version of the manuscript.
\end{abstract}

Funding: Please add: This research received no external funding.

Acknowledgments: This work was carried out with the help of the Center for International Cooperation in Agronomic Research for Development (CIRAD) in Montpellier/France and the Inter-establishment Agency for Research for Development (AIRD).

Conflicts of Interest: The authors declare no conflict of interest.

\title{
References
}

1. Djomdi; Hamadou, B.; Gibert, O.; Tran, T.; Delattre, C.; Pierre, G.; Michaud, P.; Ejoh, R.; Ndjouenkeu, R. Innovation in Tigernut (Cyperus Esculentus L.) Milk Production: In Situ Hydrolysis of Starch. Polymers 2020a, 12, 1404. https://doi.org/10.3390/po$\underline{\text { lym12061404 }}$

2. Bamishaiye E. I., Muhammad N. O. and Bamishaiye O. M. Annal of Biol. Research, 20101 (4) 274-280.

3. Ukwuru M. U. and Ogbodo, A. C. Effect of processing treatment on the quality of tiger nut milk. Pak. J. of Nutrition 2011, 10 (1): 95-100.

4. Shaker M. A., Ahmad M. G., Amany M. B. and Shereen L .N. Chufa tubers (Cyperus esculentus): As a new source of food. World Appl. Sci. J.2009, 7 (2): 151-156.

5. Builders, P. F., Mbah, C. C., Adama, K. K., \& Audu, M. M. Effect of pH on the physicochemical and binder properties of tiger nut starch. Stärke, 2014, 66(3-4), 281-293. http:// dx.doi.org/10.1002/star.201300014.

6. Onovo, J. C. and Ogaraku, A. O. Studies on some microorganisms associated with exposed tiger nut (Cyperus esculentus L.) milk. J. Biol. Sci., 2007, 7: 1548-1550.

7. Selma, M.V.; Valero, M.; Fernandez, P.S.; Salmeron, C. Adaptation of the system of risk analysis and identification and control of critical points (ARICPC) in the management of microbiological quality of tigernut milk. Alimentacion,-Equipos-y-Tecnologia. 2006; 21(165): 83-89

8. Lorougnon G. Etude morphologique et biologique de deux variétés de C. esculentus Linn. (Cyperacées) Cah. ORSTOM, Ser. Biol. $1996 \mathrm{~N}^{\circ} 10$.

9. Mujaffa, S. and Lee Loy A. “The rehydration behavior of microwave- dried amaranth (Amaranthus dubius) leaves," Food Sci. \& Nut., 2017, 5,399-406.

10. Djomdi, Ejoh, R., Ndjouenkeu, R. Soaking behaviour and milky extraction performance of tiger nut (Cyperus esculentus) tubers. Journal of Food Engineering. 2007, 78, 546- 550.

11. Minka, S.R., C.M.F. Mbofung, C. Gandon and M. Bruneteau. The effect of cooking with kanwa alkaline salt on the chemical composition of black beans (Phaseolus vulgaris). Food Chem., 1999, 64: 145-148.

12. Samuel Sefa-Dedeh, Beatrice Cornelius, and Emmanuel Ohene Afoakwa. "Effect of nixtamalization on the chemical and functional properties of maize" Food Chemistry 86, 2004: 317-324.

13. Turhan, M., Sayar, S. \& Gunasekaran, S. Application of Peleg model to study water absorption in chickpea during soaking. Journal of Food Engineering. 2002, 53: 153-159.

14. Sayar, S., Turhan, M. \& Gunasekaran, S. Analysis of chickpea soaking by simultaneous water transfer and water-starch reaction. Journal of Food Engineering. 2001, 50: 91-98.

15. Djomdi, Djoulde DR, Ejoh R, Ndjouenkeu R, Michaud P. Application of Peleg Model on Hydrothermal Treatment of Tiger Nut Tubers (Cyperus esculentus) and Effect of Dehulling Efficiency on Microbial Load. J Food Sci Nutr , 2020b, 6: 070. DOI: 10.24966/FSN-1076/100070.

16. Peleg, M. An empirical model for the description of moisture sorption curves. Journal of Food Science. 1988, 53(4): 1216-1217,1219.

17. Salimi, A., Ameri, H., et Hajighorbani, A. Investigating on effect of hot air and water temperature on kinetic of rehydration of celery by using peleg's model. Latin American Applied Research. 2019, 49(4):249-254 (2019).

18. Kaymak-Ertekin, F. \& Sultanoglu, M. Moisture sorption isotherm characteristics of peppers. Journal of Food Engineering. 2001, 47: 225-231.

19. Lomauro, C. J., Bakshi, A. S. \& Labuza, T. P. Evaluation of food moisture sorption isotherm equations, Part I: Fruits, vegetable and meat products. Lebensmittel - Wissenschaft und Technologie. 1985, 18: 111-117.

20. Wang, N. \& Brennan, J.G. Moisture sorption isotherm characteristics of potatoes at four temperatures. Journal of Food Engineering. 1991, 14: 269-282.

21. Doelhert D. C. and Wiessenborn D. P. Influence of physical grain characteristics on optimal rotor speed during impact dehulling. Cereal Chem. 2007, 84: 294-300.

* To whom all correspondences should be addressed Phone: +237 699626764

E-mail: ngdjomdi@yahoo.fr 
22. Evranus O. and Gürtas (1992). Kinetics of water absorption by legumes. In: Proceeding of the food engineering symposium. 1992, (pp 109-120) september 22-23, Turkey: Ankara.

23. AFNOR,. Recueil des normes françaises. Produit dérivé des fruits et légumes. AFNOR, Paris (France), 1999,250 p.

24. Shafaei, S.M., Masoumi A.A. and Roshan H. "Analysis of water absorption of bean and chickpea during soaking using Peleg model," J. Saudi Society of Agri. Scie., 2016, 15, 135-144.

25. Kaleta, A., Gornicki K., Choinska A., Kosiorek K. and Czyzewska A. “Modelling of rehydration kinetics of dried carrots using the Peleg model," AgriForest Eng., 2017, 69, 13-21

26. Marta J., Yuki K. and Toshihiro F. Thermal decomposition of vitamin C: An evolved gas analysis-ion attachment mass spectrometry study. Food Chemistry 129 (2011). 546-550.

27. Mosquera L.A., Sims C.A., Bates R.P. O'keep S.P. Flavour and stability of horchata de chufas'. Journal of Food Science; 1996, 01 (4) $856-861,32$ ref

28. Gilbert R. J., De Louvois J., Donavan T., Little C., Nyen N., Ribeiro C. D., Richards J., Roberts D. and Bolton F. J. Guidelines for microbiological quality of some ready-to-eat foods sampled at the point of sale. Commun Dis Public Health 2000; 3: $163-7$.

29. Shamsuddeen, U. and Magashi, A.M. Best Journal, 1(2): 26-28. 2004.

30. Muthomi, J.W., L.N. Njenga, J.K. Gatbumbi \& G.N. Chenug'wa. Plant pathology Journal 8(3): 113- 119.2009.

31. Bashir Sajo Mienda. Preliminary report of dehulling effect on the occurrence and distribution of Aspergillus flavus in maize grains stored in Mubi market. Adv. Appl. Sci. Res. 2011, 2 (5): 612-616.

32. Costa Neto, J., Silva, R., Amaral, P., Leão, M. R., Gomes, T., \& Sant'Ana, G. Extraction, chemical modification by octenyl succinic and characterization of cyperus esculentus starch. Polímeros, 28(4), 319-322, 2018.

33. Belewu, M. A., Belewu, K. V. and Bamidele, R. A. Cyper-coconut yogurt: preparation, compositional and organoleptic qualities. Afr. J. of Food Sci. and Tech. 2010, vol. 1 (1) 010-012.

34. Ejoh, R., Djomdi, Ndjouenkeu, R. Characteristics of tigernuts (Cyperus esculentus) tubers and their performance in the production of a milky drink. Journal of Food Processing and Preservation. 2006, 30, 145-163.

35. Krokida, M. K. \& Marinos-Kouris, D. Rehydration kinetics of dehydrated products. Journal of Food Engineering. 2003, 57(1): 1-7

36. Moreno-Segui, P., Pla-Perez, S., Monerris-Aparisi, C., Perez-Corbi, N., MoscardoLaboure, G. \& Aguila-Lastra, M. Influence of storage period on the microbiological quality of horchata. Alimentaria. 2000, 37(317) : 133-136. 